\title{
Southern Labor Law in the Jim Crow Era: Exploitative or Competitive?
}

\author{
Jennifer Roback $\dagger$
}

This paper explores the economic effects of certain Southern labor laws from the Jim Crow era. ${ }^{1}$ The motivation for these labor laws was to prevent movement of black laborers and increases in their wages. Throughout the period, we read of white planters pleading with one another to hold down black wages. "White men have to stick together" was the common theme. Despite all these admonitions, white employers vigorously competed with one another for black labor, and there are numerous reports of blacks leaving jobs to take higher-paying opportunities. ${ }^{2}$

Some economic historians have concluded that laws aimed at

$\dagger$ Assistant Professor of Economics, Yale University. I am grateful to Charles McCurdy for bringing this problem to my attention. Discussions with John Bigelow and Joseph Tracy have been helpful. Useful comments from Howard Dickman, Robert Fogel, and other participants in the labor law conference have been incorporated into this paper. I am grateful to all of these people. The Earhart Foundation provided financial support for this paper, which is part of a larger project on government and racism.

1 The bulk of the labor laws discussed in this paper were passed in the 1890's and early 1900 's, the era during which most of the Jim Crow legal system was put into place. See infra Chart I. Similar labor laws, however, also existed as part of the Black Codes in most states for a brief period immediately after the Civil War. The Black Codes were an attempt to maintain control over the black population similar to the control that had existed in the slavery era. Reconstruction legislation invalidated the Black Codes. See, e.g., Civil Rights Act of 1866, ch. 31, § 1, 14 Stat. 27, 27 (codified at 42 U.S.C. $\$ 1982$ (1982)). Further application of these labor laws had to await the Jim Crow period.

It should be noted that the Jim Crow period did not begin with the end of Reconstruction. There was a period of some twenty years of relatively harmonious and tolerant racial relations between Reconstruction and Jim Crow. The Jim Crow laws are commonly associated with extreme, legally mandated segregation of the races. But disenfranchisement of the black population preceded this radical segregation; indeed, disenfranchisement was necessary to accomplish segregation. Political motivations thus provided the original impetus for disenfranchisement; economic exploitation, through law and custom, came later. See infra Chart I, which includes as reference points the dates of Plessy v. Ferguson, 163 U.S. 537 (1896), and the first disenfranchisement amendments. It is best to regard Jim Crowism as a legal and political system that had economic consequences. The labor laws discussed in this paper are examples of economic legislation passed under the umbrella of disenfranchisement. For a good general history of the Jim Crow era, see C. VANN Woodward, The Strange Caregr of Jim Crow (3d rev. ed. 1974).

2 For illustrative examples, see Strphen DeCanto, Agriculture in the Postbellum South: The Economics of Production and Supply 38-40 (attempts to collude), 51-76 (competition for labor) (1974). 
repressing blacks were largely ineffective because we observe so much evidence of economic competition. Robert Higgs is a proponent of this view. ${ }^{3}$ Stephen DeCanio draws the same conclusion from an extensive econometric study that showed that farm labor was not paid less than the value of its marginal product.* Others, including William Cohen, Roger Ransom, and Richard Sutch, have argued that the laws were indeed effective at repressing blacks. ${ }^{5}$ They base this conclusion on massive amounts of anecdotal evidence that whites were taking advantage of blacks.

My approach combines elements from both these lines of inquiry. The economists are correct in describing the labor market of this period as essentially competitive, and the historians are correct in concluding that blacks were exploited. My contention is that the laws can best be understood as attempts to enforce a labor-market cartel among white employers that could not be enforced in any other way.

The planters wanted to collude to hold down black wages, both to increase their own profits and to solidify the dominant position of the white race. But, as Higgs documents, ${ }^{6}$ economic class interest and white solidarity were not adequate to overcome the economic incentive for individual planters to offer higher wages to blacks. The laws were intended to accomplish what race prejudice could not do by itself.

An analogy to import quotas illustrates the necessity of involving the government in cartel enforcement. It is obvious why import quotas are advantageous to domestic automobile manufacturers. It is also obvious that many people will find it advantageous to evade the restrictions by smuggling foreign cars to meet the excess domestic demand for them. But suppose that the car manufacturers had to bear the costs of enforcing the quotas themselves. They would have to secure the American borders, patrol the coastal waters, and inspect goods brought into the country. In short, they would have to duplicate many of the services provided by the Border Patrol, the Coast Guard, and the Customs Service. Quotas would no longer be profitable to domestic manufacturers. Simi-

s Robrrt Higgs, Competition and Coercion: Bincks in the American Economy 1865 1914 (1977).

- S. DeCANIo, supra note 2, at 12.

- The clearest example is Cohen, Negro Involuntary Servitude in the South, 18651940: A Preliminary Analysis, 42 J.S. Hrst. 31 (1976). Ransom \& Sutch, The Ex-Slave in the Post-Bellum South: A Study of the Economic Impact of Racism in a Market Environment, 33 J. EcoN. Hist. 131 (1973), promotes a similar view in a slightly different context.

- R. HigGs, supra note 3, at 37-61. 
larly, Southern planters may have found it quite profitable to collude to hold down black wages, but only as long as they could pass the enforcement costs on to state and local governments.

This paper explains how this transfer took place and suggests that both the economic historians and the conventional historians are correct in the major parts of their theses. Competition was the primary force in the agricultural labor market in this period. Race prejudice was also an important factor, and whites could successfully take advantage of blacks over a substantial period of time. Exploitation was not inherent in the capitalist system; rather, government power had to be specifically mobilized to achieve this end.

The importance of this interpretation cannot be overstated. Gary Becker's argument that discrimination is unprofitable to the discriminators and should eventually disappear from a competitive market setting ${ }^{7}$ is widely accepted. Yet differences in earnings between blacks and whites persist. This fact does not by itself refute the Becker hypothesis, since Becker's analysis explicitly excluded government intervention. ${ }^{8}$ In fact, governments in the United States-federal, state, and local-have probably never been racially neutral. Thus, it is essential that we understand and explore the interaction between a competitive market and a government that may favor certain racial groups in the economic arena. To demonstrate these points, I will show (1) what economic effects we should observe if the Jim Crow laws were perfectly enforced and (2) that some of these effects are in fact observable. Before turning to these two tasks, I will describe the laws themselves and some characteristics of the agricultural society in which they were passed.

\section{The Jim CRow Laws}

The Southern legal system aided the enforcement of a labormarket cartel through four basic types of legislation. These were (1) enticement laws ${ }^{9}$ and contract-enforcement laws, ${ }^{10}$ which were

7 Gary Beckrr, The Economics of Discrimination (2d ed. 1971).

- Id. at 19-20. In his introduction to the second edition, however, Becker does note the effect government has had in perpetuating discrimination: "The most important and pervasive influence [on restrictions on minority employment] clearly has been government action." Id. at 7. He expressly mentions "the restrictions legislated against Negroes in various southern states." Id.

- Act of Feb. 6, 1866, No. 100, 1865-66 Ala. Acts 111; Act of Mar. 6, 1875, § 8, 1874-75 Ark. Acts 230-31; Act of Jan. 12, 1865, No. 7, § 5, 1865-66 Fla. Laws 32-33; Act of Dec. 17, 1901, No. 390, $1901 \mathrm{Ga}$. Laws 63; Act of July 10, 1890, No. 138, 1890 La. Acts 178; Act of Feb. 21, 1890, ch. 56, 1890 Miss. Laws 69; Act of Feb. 24, 1905, § 3, 1905 N.C. Sess. Laws 333; Act of Dec. 24, 1880, No. 349, 1879-80 S.C. Acts 423; Act of Mar. 23, 1875, ch. 93, 1875 
designed to limit competition in the labor market to the beginning of each contract year; (2) vagrancy laws, ${ }^{11}$ which were designed to prevent blacks from being unemployed or otherwise out of the labor force; (3) emigrant-agent laws, ${ }^{12}$ which were designed to restrict the activities of labor recruiters; and (4) the convict-lease system, which provided punishment for blacks who violated the above or other laws. ${ }^{13}$ Chart I shows dates of passage for the first three sets of laws and the approximate duration of the convictlease system.

Tenn. Pub. Acts 168.

While some of these enticement statutes have been repealed, see, e.g., Act of June 11, 1943, ch. 22068, § 6, 1943 Fla. Laws 834, a good number are still on the books, see, e.g., Miss. Code Ann. \$ 97-23-29 (1972); N.C. Gen. Stat. § 14-358 (1980); S.C. Code Ann. § 4-130 (1976).

${ }_{10}$ Act of Feb. 17, 1885, No. 85, 1884-85 Ala. Acts 142; Act of May 6, 1907, No. 271, 1907 Ark. Acts 620; Act of June 8, 1891, No. 23, 1891 Fla. Laws 57; Mrss. Code AnN. $\$ 1148$ (1906); Act of Mar. 11, 1889, ch. 444, 1889 N.C. Sess. Laws 423, as amended by Act of Feb. 12, 1891, ch. 106, 1891 N.C. Sess. Laws 98; Act of Feb. 24, 1908, No. 494, 1908 S.C. Acts 536.

Many of the contract-enforcement statutes have been repealed. See, e.g., Act of Apr. 26, 1928, ch. 292, 1928 Miss. Laws 366. Some, however, have not been repealed. See, e.g., N.C. GEN. STAT. § 14-359 (1981); S.C. Code ANN. § 40.404 (1952). For a discussion of the attacks on the constitutionality of contract-enforcement legislation, see infra notes $19-26$ and accompanying text.

11 Act of Sept. 22, 1903, No. 229, 1903 Ala. Acts 244; Act of May 6, 1905, No. 283, 1905 Ark. Acts 702; Act of May 29, 1905, No. 48, 1905 Fla. Laws 97; GA. Code vol. III, $\$ 453$ (1895); Act of July 8, 1908, No. 205, 1908 La. Acts 308; Act of Feb. 29, 1904, ch. 144, 1904 Miss. Laws 199; Act of Mar. 4, 1905, ch. 391, 1905 N.C. Sess. Laws 41; Act of Dec. 22, 1893, No. 348, 1893 S.C. Acts 521; Act of Mar. 24, 1875, § 1, 1875 Tenn. Pub. Acts 188; Act of Mar. 17, 1909, ch. 59, 1909 Tex. Gen. Laws 111; Act of Jan. 2, 1904, ch. 548, § 884, 1902-04 Va. Acts 876.

Some of the vagrancy statutes have been formally repealed. See, e.g., Act of June 2, 1972, No. 1306, 1972 S.C. Acts 2490 . In any event, it is now clear that these statutes are unconstitutional and hence unenforceable. See Broughton v. Brewer, 298 F. Supp. 260 (S.D. Ala. 1969) (vagrancy statute unconstitutionally vague); Wheeler v. Goodman, 306 F. Supp. 58 (W.D.N.C. 1969) (same); Lazarus v. Faircloth, 301 F. Supp. 266 (S.D. Fla. 1969) (unconstitutionally broad).

${ }_{12}$ Act of Jan. 22, 1879, No. 175, 1878-79 Ala. Acts 205, as amended by Act of Dec. 8, 1880, No. 127, 1880 Ala. Acts 162; Act of June 1, 1903, No. 87, 1903 Fla. Laws 135; Act of Feb. 16, 1876, No. 14, 1876 Ga. Laws 17; Act of Mar. 11, 1912, ch. 94, 1912 Miss. Laws 73; Act of Feb. 6, 1891, ch. 75, 1891 N.C. Sess. Laws 77; Act of Dec. 24, 1891, No. 697, 1891 S.C. Acts 1084; Act of Apr. 7, 1917, ch. 70, 1917 Tenn. Pub. Acts 179, 189; Act of July 18, 1929, ch. 96, 1929 Tex. Gen. Laws (2d Sess.) 203; Act of Mar. 21, 1924, ch. 452, 1924 Va. Acts 679.

Some of the emigrant-agent laws have been repealed. See, e.g., Employment and Labor Agency Law, ch. 67, § 22, 1943 Tex. Gen. Laws 93. Some state emigrant-agent licensing schemes have survived. See, e.g., GA. CoDE ANN. § 34-2-6 (1982).

13 See H.R. Exec. Doc. No. 1, pt. 5, 49th Cong., 2d Sess. (1886); 5 Rep. Sec'y of the Interior 8-13 (1887); H.R. Doc. No. 33, pt. 5, 54th Cong., 1st Sess. (1896); Bull. of the Dep't of Labor 450-51 (1896); H.R. Doc. No. 906, 59th Cong., 1st Sess. (1905); Twenteter Annual Report of the Commissioner of Labor, 1905: Convict Labor 230-70 (1906); S. Doc. No. 494, 63d Cong., 2d Sess. (1914); Fzdgral and State Laws Relating to Convict Labor 1220 (1914); Bureau of Labor Statistics, Bull. No. 372, Convict Labor in 1923, at 17 (1925). 


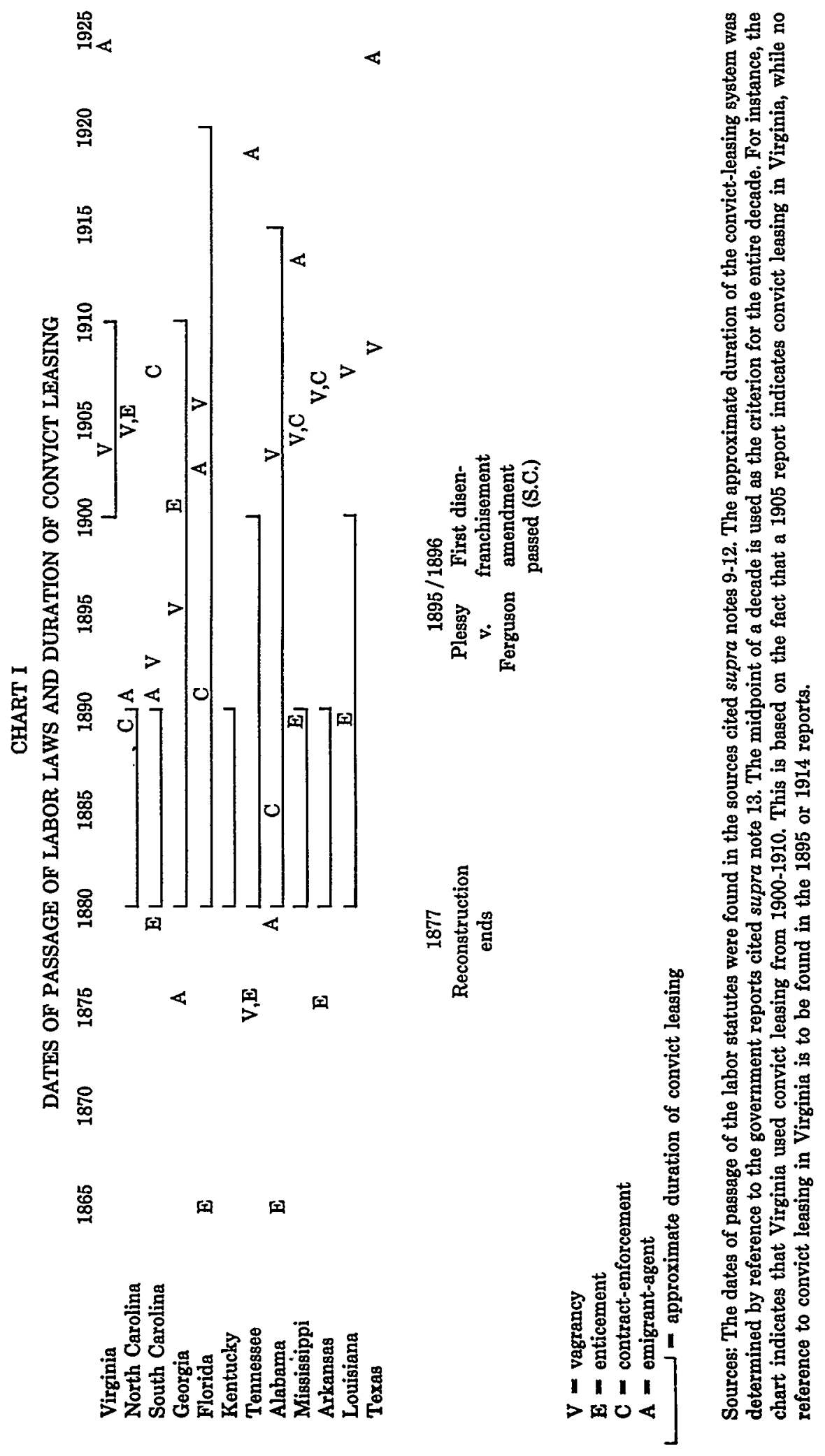




\section{A. Enticement and Contract-Enforcement Laws}

The enticement laws made it a crime for an employer to "entice" a laborer who had a contract with another employer. These laws, directed primarily at white employers, sought to prevent employers from actively competing with each other for contract labor. Enticement statutes in both criminal and civil law have a long history, going back as far as fourteenth-century England. ${ }^{14}$ Cohen states that

[s]eventeenth-century Americans often viewed the enticement of a servant as a crime against society (that is, a violation of criminal law), but later generations took the matter less seriously and treated it as a civil wrong involving only private rights. By the mid-nineteenth century criminal prosecutions for enticing a servant had become virtually nonexistent, and civil cases were rare. ${ }^{15}$

Nevertheless, ten of the eleven Southern states that passed enticement legislation made it a criminal offense, rather than a civil wrong. ${ }^{16}$

The contract-enforcement laws, directed primarily at black farm laborers, imposed criminal sanctions for the breach of an employment contract." "Under such laws . . . a laborer who signed a contract and then abandoned his job could be arrested for a criminal offense. Ultimately his choice was simple: he could either work - out his contract or go to the chain gang."18 The economic motivations behind contract-enforcement and enticement laws were simi-

14 Cohen, supra note 5 , at 35 .

15 Id.

${ }^{16}$ Act of Feb. 16, 1866, No. 100, 1865-66 Ala. Acts 111; Act of Mar. 8, 1867, No. 122, $\S 7,1867$ Ark. Acts 298, 300; Act of Jan. 12, 1866, ch. 1470, § 4, 1865-66 Fla. Acts 33; Act of Dec. 12, 1865, No. 16, § 1, 1865 La. Acts (Extra Sess.) 24; Act of Nov. 25, 1865, ch. 4, § 9, 1865 Miss. Laws 82, 85; Act of Feb. 25, 1867, ch. 124, 1866-67 N.C. Sess. Laws 197; Act of Dec. 21, $1865, \S 54,1865$ S.C. Acts 31 , 36; Act of Mar. 23, 1875, ch. 93, 1875 Tenn. Pub. Acts 168; Act of Nov. 1, 1866, ch. 82, 1866 Tex. Gen. Laws 80; Act of Feb. 20, 1866, ch. 15, § 2, 1865-66 Va. Acts 83.

17 A typical contract-enforcement statute read as follows:

Any person, who, with intent to injure or defraud his employer, enters into a contract in writing for the performance of any act or service, and thereby obtains money or other personal property from such employer, and with like intent, and without just cause, and without refunding such money, or paying for such property, refuses to perform such act or service, must, on conviction, be punished as if he had stolen it. ALA. CODE $\$ 3812$ (1886) (subsequent history discussed infra notes 19-26 and accompanying text).

18 Pete Daniex, The Shadow of Slavery: Penage in the South, 1901-1969, at 25 (1972). 
lar: both sought to limit competition for farm labor during the contract season. Competition could only legally take place at the beginning of the contract year.

The contract-enforcement statutes were constitutionally vulnerable because they had the effect of requiring specific performance of a labor contract, i.e., forced labor. For example, the Alabama Supreme Court ruled in 1891 that a conviction under the Alabama statute required proof that the worker intended to commit fraud when he signed the contract. ${ }^{10}$ Some states responded to this objection by amending their laws to include a requirement of fraud. The Alabama Legislature went further with a law deeming breach of contract "prima facie evidence of the intent to injure or defraud the employer,"20 and several states passed similar laws. ${ }^{21}$

The United States Supreme Court found the Alabama statute unconstitutional in the 1911 case of Bailey $v$. Alabama. ${ }^{22}$ The Court noted that there was "not a particle of evidence of any circumstance indicating that [the defendant] made the contract or received the money with any intent to injure or defraud his employer" and that the defendant was "stripped by the statute of the presumption of innocence, and exposed to conviction for fraud upon evidence only of breach of contract and failure to pay."23 This led the Court to conclude that

although the statute in terms is to punish fraud, still its natural and inevitable effect is to expose to conviction for crime those who simply fail or refuse to perform contracts for personal service in liquidation of a debt, and judging its purpose by its effect that it seeks in this way to provide the means of compulsion through which performance of such service may be secured. ${ }^{24}$

The Alabama statute violated the thirteenth amendment and the

1. Ex parte Riley, 94 Ala. 82, 83, 10 So. 528, 529 (1891).

${ }^{20}$ Act of Oct. 1, 1903, No. 406, 1903 Ala. Acts 345 (declared unconstitutional in Bailey v. Alabama, 219 U.S. 219 (1911)). In addition, an Alabama rule of evidence provided that the accused was not allowed to rebut the statutory presumption with testimony regarding his "uncommunicated motives, purpose, or intention." Bailey v. State, $161 \mathrm{Ala} .75,77,49$ So. 886, 887 (1909), rev'd sub nom. Bailey v. Alabama, 219 U.S. 219 (1911).

${ }_{21}$ See Act of May 6, 1907, No. 271, 1907 Ark. Acts 620; 1907 Fla. Laws 182, ch. 5678; Act of Aug. 15, 1903, No. 345, 1903 Ga. Laws 90; Act of Mar. 4, 1905, ch. 411, 1905 N.C. Sess. Laws 422; Act of Feb. 24, 1908, No. 494, 1908 S.C. Acts 1080.

219 U.S. 219 (1911).

22 Id. at 236.

24 Id. at 238. 
Peonage Act of $1867,{ }^{25}$ which prohibited involuntary servitude except to punish crime: "The State . . . may not compel one man to labor for another in payment of a debt, by punishing him as a criminal if he does not perform the service or pay the debt."26

There is some evidence, however, that employment contracts continued to be enforced without proof that the worker intended to commit fraud. Often the worker would simply not know that the law required proof of intent to defraud or that the existing law was unconstitutional..$^{27}$ Also, workers were sometimes "reclaimed" by their employers, not by law enforcement officers, and forced without a warrant to work off a debt. ${ }^{28}$ Thus, the law provided a veneer of legality for brutal activities that were actually illegal.

\section{B. Vagrancy Laws}

The second type of law used to enforce the labor-market cartel was the vagrancy law. Vagrancy statutes essentially made it a crime to be unemployed or out of the labor force. A vagrant was usually defined as "any person wandering or strolling about in idleness, who is able to work, and has no property to support him; or any person leading an idle, immoral, profligate life, having no property to support him."29 Although vagrancy was usually considered a misdemeanor, this does not mean that the punishment was trivial: misdemeanants were often sentenced to state or county chain gangs. ${ }^{30}$

Obviously, a statute that made unemployment a crime at least partially limited the amount of searching for new, more remunerative employment. More important, such statutes also increased the cost of being out of the labor force altogether. We find examples of the law being enforced for both these purposes. Blacks who traveled, even to visit relatives, faced the possibility of arrest. ${ }^{31}$ Those who were not working, that is, who were out of the labor force, were often rounded up as vagrants and put to work on local public(1982)).

2s Act of March 2, 1867, ch. 187, 14 Stat. 546 (codified as amended at 42 U.S.C. $\S 1994$

219 U.S. at 244.

27 Cohen, supra note 5 , at 38 .

${ }_{23}$ See P. Danier, supra note 18, at 3-18.

29 Act of Sept. 22, 1908, No. 229, 1903 Ala. Acts 244; see also Act of Feb. 29, 1904, ch. 144, 1904 Miss. Laws 199 (substantially similar language); Act of Mar. 4, 1905, ch. 391, 1905 N.C. Sess. Laws 412 (same).

so Cohen, supra note 5, at 50-51, 58; see also sources cited supra note 13.

31 See P. DanIEr, supra note 18, at 53; Scott, Negro Migration During the War, in 16 Premiminary Economic Studies of the War 75-76 (D. Kinley ed. 1920). 
works projects or on local farms. "So common were such practices that the Atlanta Constitution could quip to the police: 'Cotton is ripening. See that the 'vags' get busy.' "\$s2

\section{Emigrant-Agent Laws}

The final type of labor statute was the emigrant-agent law. The Southern states enacted these laws to limit the activities of agents who recruited labor from one state for work in another. These laws regulated the white recruiters, not the black workers themselves, and required agents to be licensed at fees of up to $\$ 5000$ for each county in which the recruiting took place. The laws were often passed in reaction to a wave of out-migration, ${ }^{33}$ and many states increased the fees and penalties periodically in response to further migration. ${ }^{34}$

By the time of the "great migration" of blacks to the North during World War I, we find the city of Montgomery, Alabama passing an ordinance forbidding persons from enticing laborers to leave the city to take employment elsewhere, under penalty of a $\$ 100$ fine or up to six months at hard labor, or both. ${ }^{35}$ Although these penalties may not seem severe, the ordinance was far-reaching. Anyone who printed, published, wrote, delivered, posted, or distributed any advertisement, pamphlet, or newspaper persuading people to leave the city was an emigrant agent for purposes of this law. ${ }^{86}$ One response by blacks to this type of ordinance was to subscribe to Northern newspapers, which were outside the jurisdiction of the local law. The Chicago Defender, a radical black newspaper, had a fairly wide distribution in the South and encouraged people to come to the Chicago stockyards. ${ }^{37}$

The primary economic effect of the emigrant-agent laws was to increase the cost to black laborers of obtaining information about job opportunities outside their local market area. The fact that the city of Montgomery attempted to keep its laborers shows how narrowly the local labor area might be characterized. The laws could be evaded, and were, but not without cost to the agents and to the laborers themselves.

22 Atlanta Constitution, Sept. 2, 1904, at 6, col. 1; see Cohen, supra note 5, at 50; see also id. at 51-52.

${ }^{23}$ Cohen, supra note 5 , at $39-41$.

Id. at 39.

${ }^{35}$ Scott, supra note 31, at 76 (discussing Montgomery Emigrant-Agent Ordinance, Sept. 16, 1916).

se $I d$.

27 Id. at 29-33. 


\section{The Convict-Lease System}

In addition to the laws discussed above, Southern states employed the convict-lease system, a statutory practice of leasing out state or county convicts to private firms. Convict leasing was widely used in the South, especially in the 1880's. ${ }^{38}$ Unlike other forms of convict labor in which the government maintains control over the day-to-day management of the prisoners, the lease system relinquished that control to the lessee firm. ${ }^{39}$ The firm had no interest in keeping the convicts alive past the end of their sentence or contract period, since the convicts had no "scrap" or "resale" value. In this respect, the lease system was worse than slavery: since a slaveholder receives the full capitalized value of the slave's output for his entire working life, he has an incentive to maintain the slave's health. The death rates on these chain gangs illustrate this difference: mortality rates were as high as forty-five percent. ${ }^{40}$

The significance of the convict-lease system was that its victims were often black misdemeanants, such as vagrants and violators of the contract-enforcement statutes. ${ }^{41}$ The cost of breaking any law can be gauged by a combination of the probability of punishment and the severity of punishment. ${ }^{42}$ We have no direct measure of the probability of being punished for vagrancy or contract jumping, but a forty-five percent chance of death as punishment certainly provided a powerful disincentive for illegal activity by the black laborer.

\section{Southern Agriculture in the Postbellum Era}

We must examine the agricultural sector of the South more closely in order to appreciate the circumstances that gave rise to this set of labor laws. The South had been physically and financially devastated by the Civil War. Much of the physical capital had been destroyed, and family fortunes had been wiped out. Agriculture, the South's primary business, is capital-intensive and risky. Resources must be committed at the beginning of the season, and no financial returns accrue until the end of the season. Emancipation had increased the riskiness: the human capital of slaves

ss See supra Chart I.

20hen, supra note 5 , at 55 .

40 Convicts in South Carolina had a $45 \%$ mortality rate in 1877-80; those in Tennessee had a $27 \%$ mortality rate in 1884-85. See Cohen, supra note 5, at 56-57. Cohen notes: "Convicts generally fared worse than this in other southern states." Id. at 56.

4 See id. at 57.

12 See Richard Posner, Economic Analysis of Law 165 (2d ed. 1977). 
had been transferred from their former owners to the slaves themselves. Former slave owners and others who managed farms could no longer guarantee that labor would be available during the crucial planting and harvesting seasons. Something had to be done to ensure a steady flow of labor. ${ }^{43}$

\section{A. Agricultural Contracts}

Some employers simply hired laborers on a daily or weekly basis. Such an employer faced the risk that another farmer would offer higher wages and lure his workers away. This was a particularly crucial problem at harvest time when the work could not be delayed. At harvest time, the value of the laborers was especially high, and planters were particularly vulnerable to competition. In effect, hiring workers on a short-term basis meant paying them the day-by-day value of their marginal product. Wages would be low in the mid-season and relatively high during the crucial planting and harvesting periods.

Planters resisted using this system for a number of reasons. ${ }^{44}$ They felt they were being cheated when they had to pay high wages during the peak seasons. They also disliked the uncertainty of not knowing whether they would have workers at any given time. And finally, they undoubtedly were offended by the sight of their former slaves leaving jobs whenever they chose, and for higher wages to boot.

An alternative arrangement would be a year-long contract, with the laborer being paid a steady wage over the life of the contract. This was the type of system that most of the planters seemed to prefer in the immediate postbellum period. Nevertheless, this type of contract had the disadvantage that workers needed to be paid advances on their wages in order to live. Thus, the worker often began a contract by being indebted to the employer.

Advances were provided in response to cash-flow and capitalshortage problems. Workers could seldom save enough from the previous year to be able to start the season with enough cash to live on until the crop came in, or at least until they had performed a substantial service in exchange for their wages. But even in the absence of cash-flow problems, the workers under a fixed-wage

13 See Reid, Sharecropping as an Understandable Market Response: The Post-Bellum South, 33 J. EcoN. Hist. 106, 107 (1973).

14 See R. Hrgas, supra note 3, at 39-44. 
contract received implicit advances. A fixed-wage contract pays wages that are higher than the value of the worker's labor during some periods and lower during others. This means that sometimes the employer will be giving implicit advances on the employees' wages and at other times the employees will be making implicit payments to the employer. ${ }^{45}$ In the agricultural context, the harvest is the high-productivity time when the worker earns less than the value of his labor. But during the rest of the contract period, the worker receives implicit advances from the employer.

This creates the most obvious disadvantage of the fixed-wage contract system. The workers had an incentive to cheat on the contract by quitting right before the harvest. ${ }^{46}$ This provided the justification for the contract-enforcement and enticement statutes. The Assistant Attorney General of Mississippi argued that enticement laws were necessities "in an agricultural state where long time contracts are made and monies necessarily advanced in anticipation of the fulfillment of a contract."247 Thus, the situation was inherently risky. If the planter offered a fixed-wage contract, he faced the risk that the employees would breach at the harvest. On the other hand, if the planter hired and paid employees on a short-term basis, he still could not guarantee that he would have enough harvest labor. In addition, he could not predict the wage that the competitive market would demand.

With all these problems, it would be surprising if some alternative form of contract did not emerge. By 1867, "a majority of planters and laborers were ready to explore alternative crop-making arrangements"; in fact, sharecropping contracts and rental contracts developed after the Civil War and soon became widespread..$^{48}$ A typical sharecropping contract required the worker, or "cropper," to work the whole season in return for a share (usually a quarter to a half) of the crop when it was sold. Money would be advanced to the cropper and would later be deducted from his share. Usually the landlord provided fertilizer, mules, equipment, and management skills. Some contracts specified noncultivation

45 Readers who are familiar with the theory of firm-specific capital investments in onthe-job training will see why this is true. The firm implicitly pays for the firm-specific capital by paying a wage that is higher for a time than the value of marginal product.

46 To be sure, planters could, and often did, renege on contracts that called for them to provide services such as medical care. These contracts were enforced by the Freedman's Bureau in the immediate postbellum period, but breaches by the planters rarely found their way into court after Reconstruction. See P. DANIEL, supra note 18, at 20 n.3.

47 Cohen, supra note 5 , at 37 .

48 Reid, supra note 43 , at $110-11$. 
tasks, such as barn repair and the like, and stipulated that the cropper would receive a smaller share of the crop if he failed to perform these tasks. ${ }^{49}$ Sharecropping contracts still involved advances to the workers, but they had the advantage of reducing default risk to the employer by giving the worker an incentive to stay and work out the contract. The employer usually sold the crop and could simply deduct what he was owed when he paid the cropper. Since the worker had a stake in the crop on that particular farm, he was not likely to abandon his job, even for the promise of a high wage. Nor was he as likely to shirk in his effort as he would be under a fixed-wage contract because he shared with the employer the risk of a crop failure. ${ }^{\text {so }}$

Rental contracts usually required the tenant to pay a fixed rent for the land he cultivated.51 This was sometimes a fixed dollar amount, sometimes a fixed quantity of the crop. The rental system placed all the risk of crop failure on the tenant and, as with sharecropping, minimized his incentive to shirk or run away.

By 1880, twenty-eight percent of Southern farms were sharecropped and seventeen percent were rented. ${ }^{52}$ This suggests that the contract-enforcement and enticement statutes were not really needed for agricultural stability. Alternative crop arrangements existed that could reduce the problems that the laws were meant to address, and these alternatives were used by a significant number of employers. The sharecropping and rental contracts actually made the tenants much more vulnerable to breach of contract than they had been. In fact, most authors have concentrated on the weak position of the indebted tenants relative to the landlord.ss

\footnotetext{
4? See id. at 114-18. Reid quotes one contract in full. The relevant passages from that contract are:

If any cropper shall from any cause fail to repair his fence as far as 1000 rails will go, or shall fail to clean out any part of his ditches, or shall fail to leave his ditch banks, any part of them, well shrubbed and cleaned when his crop is laid by, or shall fail to clean out stables, fill them up and haul straw in front of them whenever he is told, he shall have only two-fifths (2/5) [instead of one-half $(1 / 2)$ ] of the cotton, corn, fodder, peas and pumpkins made on the land he cultivates.
}

Id. at 129.

so Risk-sharing is the point that economists have usually focused on. E.g., Reid, supra note 43 , at 120-23.

si Id. at 110.

s2 Id. at 111 .

B2 E.g., Ransom \& Sutch, Debt Peonage in the Cotton South After the Civil War, $32 \mathrm{~J}$. EcoN. HIST. 641 (1972). 


\section{B. Debt Peonage}

The term "debt peonage" refers to any situation in which a worker is forced to labor to pay off a debt. It is used to refer to the plight of the sharecropper locked into a sharecropping arrangement by being perpetually in debt-both to his landlord and to local merchants wielding their monopoly power as the sole source of rural credit.

Contemporary observers and historians alike have condemned the debt-peonage system as exploitative of the tenant farmer, as a hindrance to Southern economic development, and as a moral outrage. Ransom and Sutch describe this widely held view:

Sharecropping allowed the exploitation of the small farmer by the monopolistic financial structure dominated by the local merchant. Unable to obtain alternative sources of credit for supplies he needed, the small farmer was forced to pledge his future crop as a lien against credit advanced for the growing season. The crop lien bound the farmer to the merchant and restricted his options to buy elsewhere or dispose of his crop in the most advantageous manner. Through use of his monopoly power, the merchant was able to insist that the farmer concentrate on the production of cotton at the sacrifice of food for home consumption, thereby forcing the farmer to buy his provisions from the merchant. The credit prices charged for these supplies were exorbitant, reflecting not only the local merchant's inefficiency, but his exploitative powers as the sole source of rural credit. ${ }^{.4}$

The weakness of this emphasis on debt peonage as the source of rural exploitation is that the shadow of debt hanging over the worker's head gave him every incentive to "declare bankruptcy" by running away. This would be the obvious escape hatch from the vicious cycle of debt, unless the system included some means of preventing runaways and of compelling specific performance of a labor contract. Without such constraints, the possibility of such "bankruptcy" would place a limit on the interest rates the merchants could charge and on the extent to which the landlord could exploit the tenant through unfair crop division.

Exploitation of tenant farmers through debt peonage depended upon enforcement of the labor laws discussed above. Hence the focus on debt peonage as the source of exploitation in so much

st Id. at 642 . 
of the literature is simply a red herring. Debt peonage by itself should not be the subject of the inquiry; rather, we should examine the legal system that allowed forced labor. A system that can force people to work can do so whether or not they are indebted. Debt might provide a pretext, but other pretexts could be provided as well; indeed, a pretext may not be needed if the power to coerce exists. Rounding up vagrants and forcing them to work on publicworks projects is the functional equivalent of the debt-peonage system. ss $^{\text {so }}$

Since the term peonage can encompass any situation in which a worker is forced to work in order to pay off a debt, some authors include the criminal-surety system in their discussions of debt peonage. ${ }^{56}$ This system has been described as follows: "The plan is to accuse the negro of some petty offense, and then require him, in order to escape conviction, to enter into . . . a contract, under the terms of which his bondsman can hire him out until he pays a certain sum." "sz In other words, the black would be indebted to the surety who paid his bail and thus be obligated to "work off" his debt. The criminal-surety peon differed from an agricultural peon because he could not run away. Purchased convicts were often worked in chains and locked up at night. The black was often led to believe that he was a convict, even though he was legally free because someone had paid his bail and court costs. ${ }^{68}$ Local sheriffs and judges were usually quite cooperative in enforcing the terms of the contract the black signed with the employer. Laborers who managed to escape were often caught and faced even higher penalties to work off than before. ${ }^{58}$ Further, as one United States district attorney noted in 1903, " '[w] negro is nearing an end, . . . he is rearrested upon some trumped up charge and again carried before some bribed justice and resentenced to an additional time." "'oo

Certainly the most egregious instances of physical abuse, beatings, and even murder were criminal-surety cases. ${ }^{61}$ This is not surprising considering that the power of the law stood behind the purchase of convicts in a way that it did not for the rural merchant. In addition, a merchant's solvency depended on the

\footnotetext{
ss See Cohen, supra note 5, at 32-33. For other examples, see id. at 50-51.

so See, e.g., P. DANIRL, supra note 18, at 24-25.

s7 Id. at 45 .

ss Id.

- Cohen, supra note 5, at 54.

- P. DanIRL, supra note 18, at 47.

${ }^{\circ}$ See id. at 110-31.
} 
cropper paying him something rather than running away. The criminal-surety employer had less fear that his workers would run away, and if they did he could replace them at the modest cost of the bail of another misdemeanant. His incentive, much like that of the lessee of convicts, was to extract as much work as possible from a laborer in a fixed period of time.

Thus, we must conclude that agricultural peonage and criminal-surety peonage are different and should not be lumped together under the heading of "peonage." We can also conclude that criminal-surety peonage was the far more abusive system.

\section{The Economics of Exploitation}

The term "exploitation" has been used very loosely by many authors to describe the labor market for black farm workers in this period. ${ }^{62}$ The purpose of this section is to offer three possible economic meanings or interpretations of the term "exploitation." I call these three alternatives (1) monopsony, (2) limited or closedsector mobility, and (3) forced labor, and I will discuss the combinations of labor laws that might give rise to each of the three.

\section{A. Monopsony}

Monopsony occurs in a market with only one buyer of labor. The pure monopsony case with literally a single buyer of labor is familiar to economists. The single buyer takes the supply curve as given, hires labor at the intersection of the values of the marginal product and marginal factor costs, and pays a wage determined by the supply curve of labor. (See Figure 1.) The wage is less than the value of the marginal product. Monopsony is the only one of the three scenarios I discuss for which this is true. Monopsony makes workers worse off relative to the competitive market and yields rents to the employers. It is in this sense that monopsony can be regarded as exploitative. ${ }^{63}$

What legal restrictions would be necessary to generate a monopsony-like situation in a market that normally has many buyers? The simplest way to create monopsony is to restrict labor mo-

62 See, e.g., Cohen, supra note 5; Domar, Causes of Slavery or Serfdom: A Hypothesis, 30 J. Econ. Hist. 18 (1970).

es Stephen DeCanio clearly limits his definition of exploitation to the monopsony model when he tests for equality of wage and value of marginal product. Finding that wages are no less than and sometimes greater than the value of the marginal product, he concludes that workers were not exploited. But this does not mean that exploitation in a broader sense did not occur. See infra text accompanying notes 76-80. 


\section{FIGURE 1: MONOPSONY}

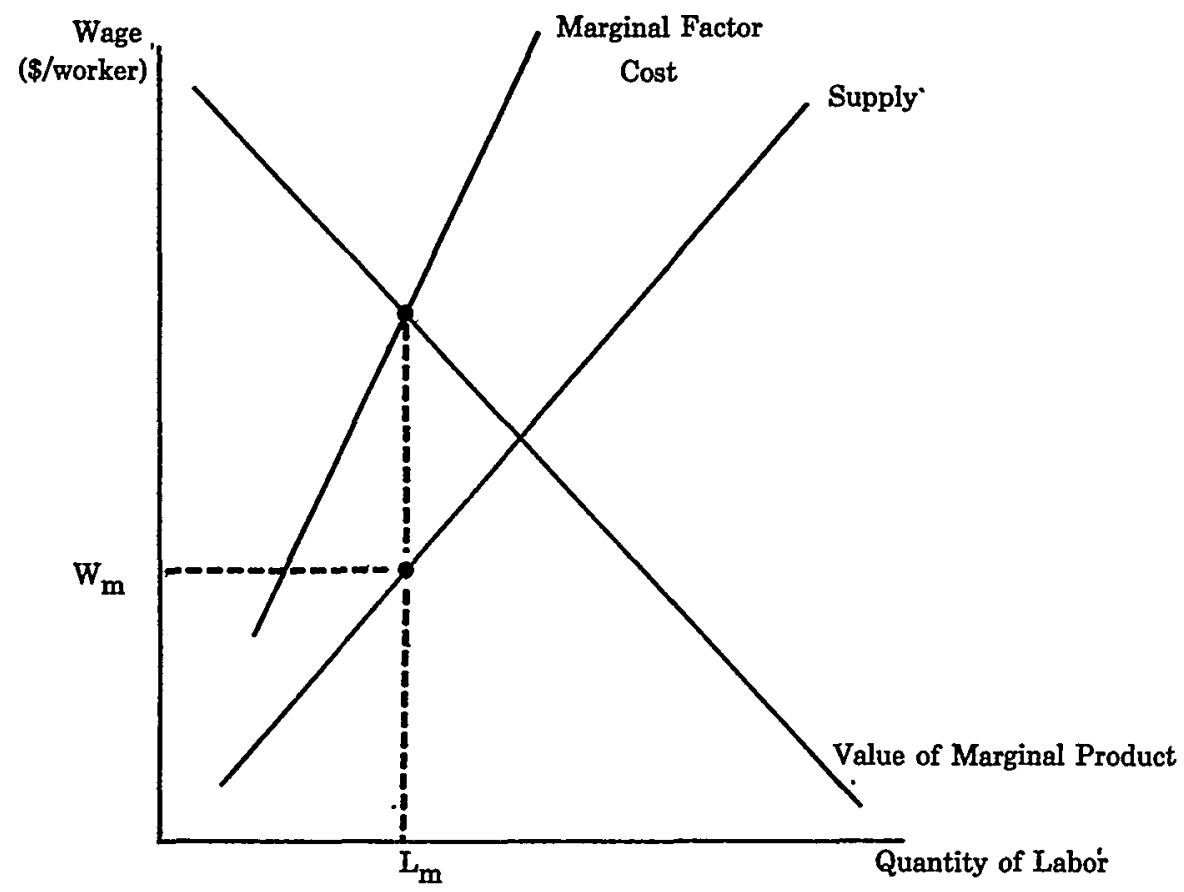

$W_{m}$ is the wage chosen by the monopsonist and $L_{m}$ is the quantity of labor chosen by the monopsonist. The marginal cost of hiring additional labor is greater than the wage because the monopsonist must pay higher wages to induce additional workers to supply labor. This higher wage must be paid to all workers, not only to the last worker hired. This is why the marginal factor cost curve lies above the supply curve.

bility completely. If a worker is unable to change jobs, his employer has monopsony power. But, as an exception to this restriction of mobility, the worker retains the option of dropping out of the labor force altogether. Free exit distinguishes monopsony from forced labor. In monopsony, the employer is constrained to offer wages that will induce the workers to stay in the labor force. ${ }^{64}$

4 This is what creates the upward-sloping supply curve of labor. See supra Figure 1. In a forced-labor situation, the supply curve of labor is horizontal at the subsistence wage, see infra Figure 3, because the employer need not offer wages that the workers will voluntarily accept. 
The contract-enforcement and enticement laws were designed to limit mobility during the contract year but had little effect on competition for contracts at the beginning of the season. It is possible to imagine the vagrancy statutes being used to limit mobility at the beginning of the contract period. This would require almost total collusion among the planters, however, since many of them might find it privately worthwhile to search for new laborers each year. The case for monopsony rests on strict enforcement of the contract-enforcement and enticement laws and a particular application of the vagrancy laws. I regard monopsony as the least plausible of the three exploitation scenarios I consider.

\section{B. Limited or Closed-Sector Mobility}

A less restrictive interpretation of these labor laws is that they reduced sectoral or regional mobility but had little effect on mobility from farm to farm in a given area. Limiting mobility would have prevented reductions in the supply of labor to Southern agriculture and thus maintained a relatively low wage to black farm labor. (See Figure 2.) Without these restrictions, labor would have migrated from the low-wage Southern agricultural sector to the higher-wage urban sector in either the North or the South. This migration would have increased agricultural wages and decreased other wages until the wages in the two sectors were equal. The wage paid the black workers would equal the value of the marginal product because limited local competition would prevent monopsony; hence, there would be no exploitation in DeCanio's sense of the word, nor would there be any economic "rents." But a lower wage would increase profits for firms while reducing the utility of workers. In this sense, limiting mobility can be regarded as exploitation since the workers would not be earning the wage they would earn in a competitive market.

The limited-mobility scenario seems quite plausible in the Jim Crow context. In addition to the contract-enforcement, enticement, and vagrancy laws, the emigrant-agent laws may have limited sectoral mobility. The emigrant agents functioned very much like labor arbitrageurs, bringing costly information about opportunities in higher-wage areas to workers in lower-wage areas. The emigrantagent laws made this type of arbitrage activity more costly and hence reduced the amount of information available to black farm laborers. This, in turn, must have increased the costs of moving to a new location. There could be extensive mobility within a local area, and hence the local market could be effectively competitive. But mobility between counties or states might be quite limited. 
FIGURE 2: LIMITED MOBILITY
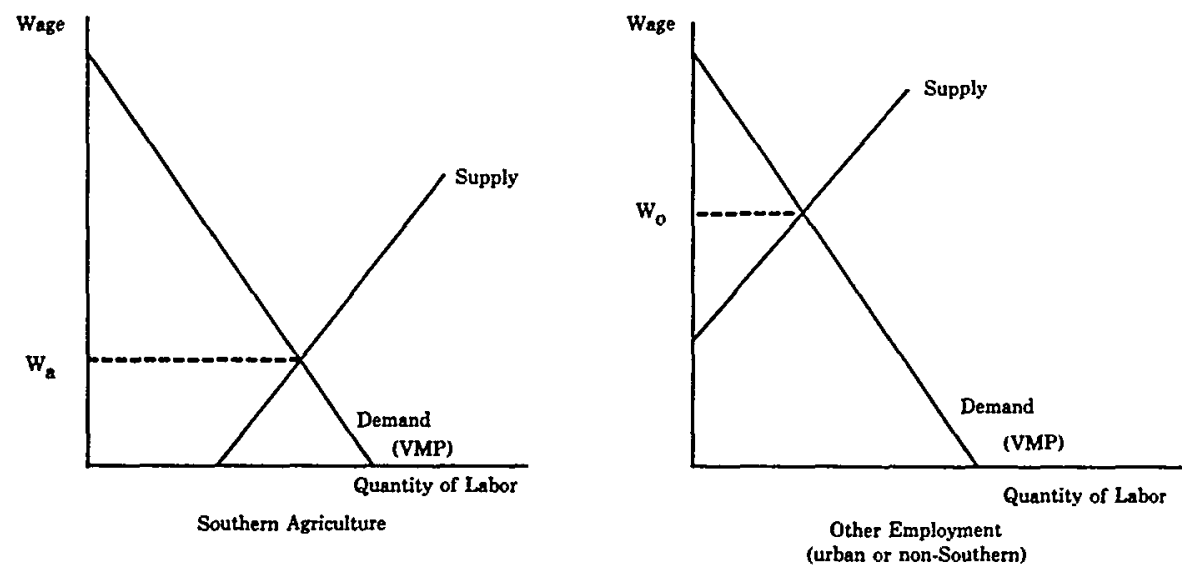

These graphs represent the supply and demand of labor to two markets, the Southern agricultural labor market and the remainder of the labor market (which includes urban employment in the South and all employment outside of the South). $W_{a}$ and $W_{0}$ are the wages paid in these two respective sectors. Since $W_{0}$ is greater than $W_{a}$, we should expect to see worker migration from the agricultural sector to the other sector until $W_{\mathrm{a}}$ rose and $W_{\mathrm{o}}$ fell to approximate equality. Because the restrictions on worker mobility described in this paper prevented this migration, $W_{a}$ remains lower than $W_{0}$.

There is some anecdotal evidence to support this view. Reported cases of black migration being prevented by violence usually involved blacks leaving the county or the state. Cohen cites one example:

In September 1937 Warren County, Georgia, cotton growers sought to prevent the farmers of adjoining Glascock County from enticing away their black laborers. Desperate for hands, the men from Glascock County had offered almost to double the rate being paid for cotton pickers in Warren County. Unwilling to abide by the law of supply and demand, Warren County planters mobilized to stop the depletion of their labor force. Sheriff G. P. Hogan described the ensuing events: "There was no trouble, although a number of [the Warren County men] carried guns and fired them into the air. They told the pickers there was plenty of cotton to pick in Warren County and asked them to stay home and pick it. They de- 
cided to stay."

Emmett J. Scott reports numerous instances of legal and extralegal violence designed to prevent blacks from moving to Northern cities, including harassment at train stations and the actual delaying of trains. ${ }^{68}$ We have already seen the attempt of Montgomery, Alabama to prevent labor from leaving the city. ${ }^{67}$

\section{Forced Labor}

It has been claimed that the Southern legal system was a forced-labor system for black workers. ${ }^{68}$ From an economic standpoint, "forced labor" means that the market wage is lower than the reservation wage ${ }^{69}$ and that the worker cannot drop out of the labor force. At the wage $W_{f}$ in Figure 3 , only $L_{s}$ is voluntarily supplied while $L_{d}$ is the quantity of labor demanded. Satisfying this demand requires forcing people to work. Note that $W_{f}$ equals the value of marginal product, but not the supply price of labor, and is thus exploitative.

The textbook example of this type of wage control is military conscription. The government has the authority both to set the wage at an artificially low level and to compel young men to work in the armed forces. The situation may be deemed exploitative because the government benefits at the expense of the workers who are forced to work at artificially low wages.

What aspects of the Southern legal system could have given forced-labor power to whites? Clearly, convict leasing involved forced labor. The convicts could not refuse to work and the county and the lessee firms could decide on an implicit or explicit wage for the convicts. The criminal-surety system ${ }^{70}$ also could be considered forced labor.

While no one would deny that convict leasing involved forced labor, the interesting questions are how convict leasing affected the market in free labor and whether any other combinations of laws might have simulated a forced-labor situation. Due to productmarket competition, convict leasing tended to lower the price of free labor. Firms that leased convicts at a low rate and paid low

${ }^{65}$ Cohen, supra note 5, at 59.

so Scott, supra note 31, at 72-85.

-2 See supra text accompanying notes 35-36.

es See Cohen, supra note 5, at 30-33.

69 The reservation wage is that point on the worker's indifference curve at which he would choose leisure over work at the offered wage.

${ }^{70}$ See supra text accompanying notes 56-61. 
FIGURE 3: FORCED LABOR

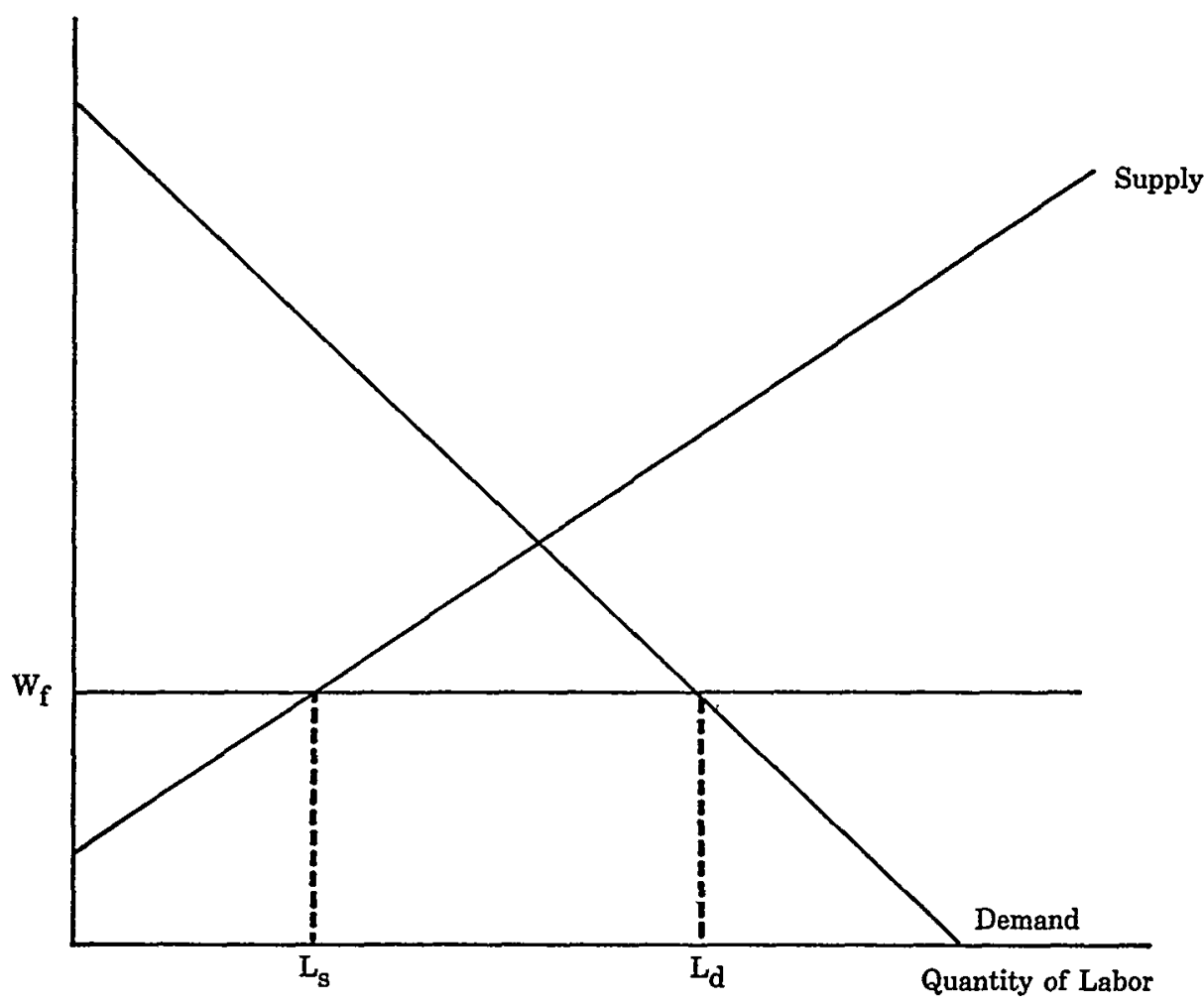

$\mathrm{W}_{\mathrm{f}}$ is the wage paid to forced labor.

$\mathrm{L}_{\mathrm{s}}$ is the quantity of labor supplied at wage $W_{\mathrm{f}}$.

$\mathrm{L}_{\mathrm{d}}$ is the quantity of labor demanded at wage $W_{\mathrm{f}}$.

$\mathrm{L}_{\mathrm{d}}-\mathrm{L}_{\mathrm{s}}$ is the quantity of labor that must be extracted through the use of force.

The supply curve of labor represents the maximum quantity of labor voluntarily offered at any given wage. Since employers can force workers to supply labor, regardless of the wage offered, they can ignore the supply curve for all wages greater than $W_{f}$.

maintenance costs would have had a competitive advantage over firms that did not use convicts. Thus, free-labor firms, ceteris paribus, would have been undersold and driven from the market.

Before they were driven out, however, we would expect to see the free-labor firms trying at least one of two strategies. The first would be to try to obtain convict labor themselves. This would have bid up the rental prices of the convicts until the prices of using convict and free labor were equalized. It would also have had the effect of transferring forced-labor rents from the firms to the 
county governments. This would be comparable to the purchase of a slave, whose price capitalizes the market value of his product over his lifetime.

The other strategy that free-labor firms could have used would be to try to have convict leasing abolished in their particular industry. This was, in fact, the more common strategy. The congressional hearings on the subject are filled with complaints from businessmen about unfair competition from firms employing convict labor. ${ }^{71}$ This suggests that they had some influence, perhaps a decisive influence, on the final policy of using convict labor only for government projects and not for private industry. Most states had abolished convict leasing by $1890 .^{72}$

For the states where convict leasing persisted, however, we must examine more closely its long-run effects on the labor market. In particular, we must ask (1) how maintenance expenditures (the implicit wage paid to convicts) compared with the wages of free labor and (2) how competition for convicts affected the labor market. To answer the first question, we must again distinguish between slavery and conscripted convict labor.

1. Implicit Wages of Convicts. Two separate but related considerations are the replacement cost of a worker and the length of the planning horizon. In conscription situations, the replacement cost is fairly low relative to the capitalized value of lifetime earnings. Certainly an additional vagrant or chicken thief could be rounded up for less than it would cost to maintain leased convicts adequately. The lower the replacement cost, the greater the incentive to use more laborers and to lower expenditures on maintenance. This is a factor that tends to keep convict wages lower than free-labor rates.

The length of the planning horizon also differs between slave and free labor on the one hand and convict labor on the other. The free laborer cares about his entire normal lifespan and the slaveowner cares about the entire working life of the slave. The reservation wage is set at a level high enough to maintain a worker's health during his expected lifespan. The lessee of convicts and the county care only about the worker over the term of his prison sentence. ${ }^{73}$ As a consequence, neither has an economic incentive to

${ }^{71}$ See, e.g., H.R. REP. No. 906, 59th Cong., 1st Sess. 47-172 (1905); Burgau of LABor Statistics, Bull. No. 372, Convict LaBor in 1923, at 107-68 (1925).

${ }^{72}$ See supra Chart I.

73 This would not be true if the county were able to sell the worker at the end of the term. 
care whether the convict survives beyond the end of his term. This again induces maintenance expenditures below those that a free laborer would spend on himself or that a slave owner would spend on his slave.

2. Competition for Convict Labor. To understand the effects of competition for convict labor, we need to modify the diagram in Figure 3 to account for the two components of labor costs: maintenance costs and rental costs. (See Figure 4.) With competition for convicts, the total price paid for a convict should equal the wage for comparable free labor. Thus, the rental rate charged by the county should rise to $R_{c}$ and the quantity demanded fall to $L_{c}$. This assumes that the quantity of convicts supplied is responsive

FIGURE 4

COMPETITION FOR CONVICT LABOR

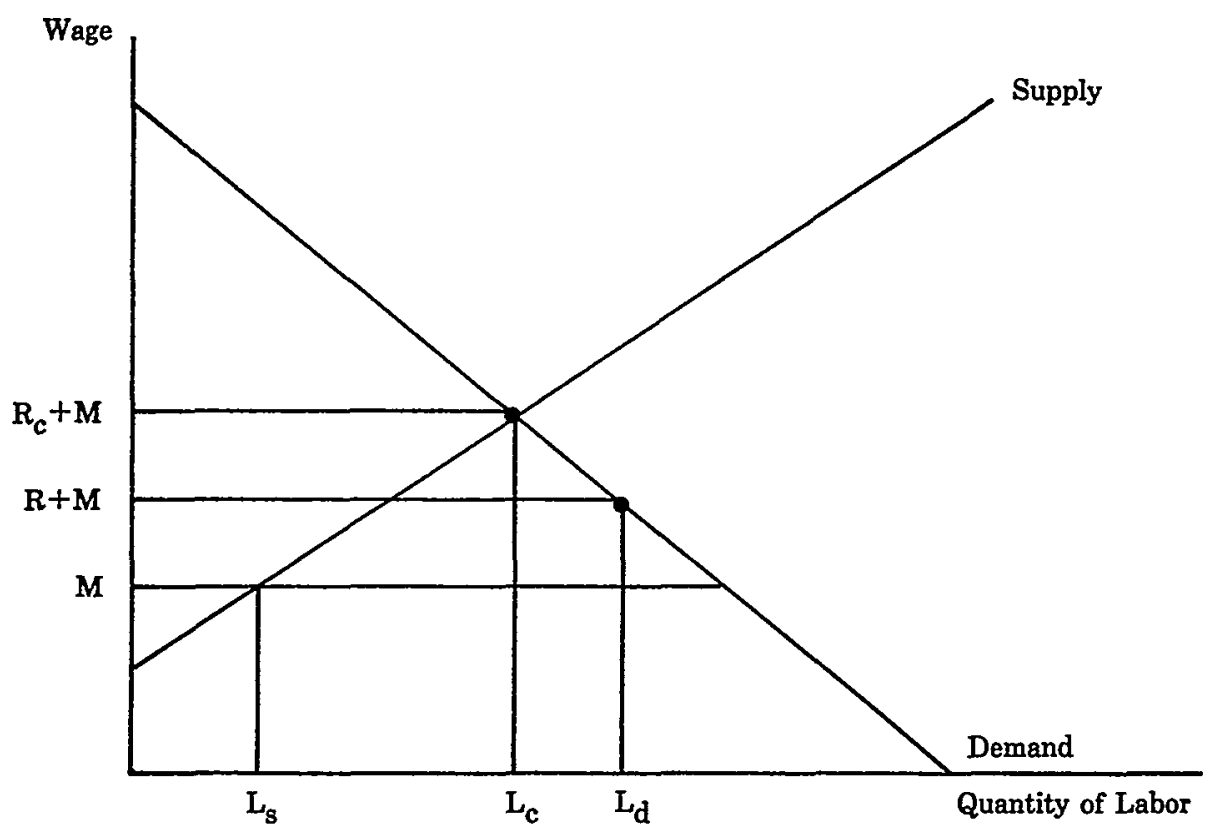

$M$ is maintenance costs; or the implicit wage received by the worker.

$\mathrm{L}_{\mathrm{s}}$ is the amount of labor voluntarily supplied at the wage.

$R$ is the rental rate paid to the county for the convicts.

$R+M$ is the total cost of a worker.

$L_{d}$ is the amount of labor demanded at $R+M$.

$\mathrm{L}_{\mathrm{d}}-\mathrm{L}_{\mathbf{g}}$ is the amount of labor that must be forced.

$R_{c}$ is the competitive rental rate, i.e., the rate the county receives after vigorous competition among employers for convict labor. 
to market forces and that the level of maintenance provided by employers does not change in response to higher rental rates. I have also assumed that changes in the quantity of convict labor have a negligible impact on the supply of free labor.

Yet even with competition, convict labor was exploitative. The implicit wage received by the convicts was both less than the value of their marginal product and less than their reservation wage. The price paid by the employer equaled the value of the marginal product, but the employee did not receive the entire wage because $R$ was remitted to the government. The county or state government gained at the expense of the convicts.

3. Forced Labor in the Free Labor Market. Could a combination of laws create something like forced labor in an ostensibly free-labor market? Two conditions would be needed: (1) dropping out of the labor force would have to be prohibited ${ }^{74}$ and (2) competition for labor would have to be curtailed so that wages would not be bid up. The vagrancy law certainly attempted to prevent laborforce exit. In fact, that is probably a fairer statement of the law's effect than that it prevented job-search unemployment. It may have tried to reduce search, but it most surely tried to reduce exit. The enticement and contract-enforcement laws attempted to reduce competition among employers for agricultural workers. The purpose of this attempt, as we have seen, was to reduce the competitive pressure for increased wages. ${ }^{75} \mathrm{Had}$ this combination of laws been enforced, a forced-labor situation may well have existed.

\section{The Evidence of Exploitation}

The foregoing discussion has served two purposes. First, it has offered various economic scenarios that might be classified as "exploitative"; second, it has shown the types of evidence that would be consistent with those various scenarios. The following discussion presents evidence that is consistent with the hypothesis that some exploitation took place. I do not attempt to distinguish among the various types of exploitation to prove once and for all that one particular type did take place. My aim is to persuade the reader (1) that there is evidence to support the contention that farm operators were able to exploit black farm laborers and (2) that it was not the spontaneous workings of the market that made

n4 Otherwise workers could avoid low wages by not working. See supra note 69 and accompanying text.

${ }^{75}$ See R. Higgs, supra note 3, at 39-44. 
this possible, but rather the capture of the legal apparatus by those who wished to discriminate.

I will examine three types of evidence. The first is evidence of productivity, drawn from Stephen DeCanio's excellent econometric study. The second is evidence of the relative mobility of blacks and whites in the Southern states. Finally, I shall look briefly at relative rates of urbanization for blacks and whites, both Southern and Northern.

\section{A. Evidence of Productivity}

Stephen DeCanio did a very thorough econometric study of agricultural productivity for ten states in the South. ${ }^{76} \mathrm{He}$ estimated Cobb-Douglas production functions ${ }^{77}$ for agriculture using the decennial census data from 1870 to 1910 . DeCanio compared his estimate of labor's share of output with the share that tenants customarily received under sharecropping arrangements (from onefourth to one-half of the crop). ${ }^{78}$ Since his estimates of labor's share lay well within that range, he concluded that the market was competitive and that there is no evidence of exploitation. ${ }^{79}$

My disagreement with DeCanio is not over his evidence, but over his interpretation of that evidence. By showing that wages equaled the value of marginal product ( $W=V M P)$, he has only shown that monopsony did not exist. The theoretical discussion above shows that the conditions required for monopsony are so stringent that its existence is a priori implausible. The discussion also shows, however, that alternative definitions of exploitation are perfectly consistent with W=VMP and some form of limited competition. DeCanio's evidence does not rule out the possibility that either a closed-sector or a forced-labor situation existed.

In fact, some of DeCanio's evidence actually supports these hypotheses. One implication of both models is that the observed marginal productivity of blacks should be less than that of whites.

7* $\mathrm{S}$. DeCaño, supra note 2, at 140-85, 220-40.

77 The Cobb-Douglas production function is a weighted geographic mean relating quantity of output $(\mathrm{Q})$ to quantity of labor $(\mathrm{L})$ and capital $(\mathrm{K})$. The function takes the form

$$
\mathrm{Q}=a \mathrm{~L}^{\alpha} \mathrm{K}^{\beta}
$$

where $a, \alpha$, and $\beta$ are the parameters to be estimated. The coefficients $\alpha$ and $\beta$ on the inputs represent both the marginal product of that factor and the share of that factor in total output. The important feature of the function for DeCanio's work is that the value of $\alpha$ represents both the marginal product of labor and the average product of labor.

78 $\mathrm{S}$. DECANIO, supra note 2, at 140-64.

78 Id. at 165-71. 
Since blacks are being artificially attached to the labor market in both cases, their wages, and hence their marginal product, should be lower than those for whites.

DeCanio estimates the relative marginal products of blacks and whites in his production functions. ${ }^{80}$ Table 1 shows a summary of his results with the date of passage of each state's vagrancy law and a few of the other important laws superimposed. The table displays the years and states for which the difference between black and white productivity differed significantly from zero. A positive coefficient indicates that blacks had a higher marginal productivity than whites while a negative coefficient signifies the reverse.

The table shows that the negative coefficients occur in the years after 1890, with the single exception of Arkansas in 18701880. As can be seen, the states that have lower black marginal productivity had passed vagrancy statutes within the preceding decade. Some of the states with vagrancy laws appear not to be linked with lower black marginal productivity; however, nearly all these states passed their vagrancy laws very late in the period under study. The bulk of this part of DeCanio's evidence is consistent with the hypothesis that restrictive labor laws, particularly the vagrancy laws, limited black mobility and depressed black wages.

\section{B. Migration Evidence}

Limited mobility of black workers is an essential feature of all three models presented above. Data on mobility within states is not available, but we do have data for net migration in and out of states. The hypothesis is that restrictive legislation reduced black migration rates relative both to their previous levels and to the migration rates for whites.

Table 2 displays net migration rates for each race by state from $1870-80$ to $1900-10$. The first thing to note is that the primary character of migration for both races was outmigration from the Southern states. The exceptions were Florida, the southwestern states of Arkansas and Texas, and, to a lesser extent, Louisiana; this shows that the general westward movement of the American population during this period took place within the South as well. 
TABLE 1

MARGINAL PRODUCTIVITY DIFFERENTIALS ${ }^{a}$ BY RACE FOR TEN SOUTHERN STATESb AND FOUR CENSUS PERIODS

\begin{tabular}{llll}
$1870-1880$ & $1880-1890$ & $1890-1900$ & $1900-1910$ \\
\hline & & Vagrancy
\end{tabular}

North Carolina

$>0$

$>0$

$>0$

(1905)

\begin{tabular}{|c|c|c|c|c|}
\hline North Carolina & $>0$ & $>0$ & $>0$ & $>0$ \\
\hline & & & $\begin{array}{c}\text { Vagrancy } \\
\text { (1894) }\end{array}$ & $\begin{array}{l}\text { Contract- } \\
\text { Enforcement } \\
\text { (1908) }\end{array}$ \\
\hline South Carolina & $=$ & $=$ & $<0$ & $<0$ \\
\hline & & & $\begin{array}{c}\text { Vagrancy } \\
\text { (1895) }\end{array}$ & \\
\hline Georgia & $=$ & $>0$ & $<0$ & $=$ \\
\hline & & & & $\begin{array}{c}\text { Vagrancy } \\
\text { (1905) }\end{array}$ \\
\hline Florida & $=$ & $=$ & $=$ & $=$ \\
\hline & $\begin{array}{c}\text { Vagrancy } \\
\text { (1875) }\end{array}$ & & & \\
\hline Tennessee & $=$ & $=$ & $=$ & $=$ \\
\hline & & $\begin{array}{c}\text { Contract- } \\
\text { Enforcement } \\
(1885)\end{array}$ & & $\begin{array}{c}\text { Vagrancy } \\
\text { (1903) }\end{array}$ \\
\hline Alabama & $=$ & $=$ & $<0$ & $<0$ \\
\hline & & & & $\begin{array}{c}\text { Vagrancy } \\
(1904)\end{array}$ \\
\hline Mississippi & $=$ & $>0$ & $=$ & $<0$ \\
\hline & $\begin{array}{l}\text { Enticement } \\
\text { (1875) }\end{array}$ & & & $\begin{array}{c}\text { Vagrancy } \\
\text { (1905) }\end{array}$ \\
\hline Arkansas & $<0$ & $=$ & $=$ & $<0$ \\
\hline & & & & $\begin{array}{c}\text { Vagrancy } \\
\text { (1908) }\end{array}$ \\
\hline Louisiana & $=$ & $>0$ & $=$ & $=$ \\
\hline rexas & $=$ & $=$ & $=$ & $\begin{array}{c}\text { Vagrancy } \\
(1909) \\
=\end{array}$ \\
\hline
\end{tabular}

Source: S. DeCanto, Agriculture in the Postbellum South: The Economics of ProducTION AND SuppLy, at Table 4.1 (1974).

a Each entry represents the sign of the coefficient on the relative contribution of black and white labor to total product for that state in that year. A positive coefficient indicates that blacks have greater marginal productivity (at standard levels of statistical significance).

b Virginia and Kentucky were not included in DeCanio's study. 
TABLE 2

RATES OF NET MIGRATION OF NATIVE WHITES PER 1000 NATIVE WHITE POPULATION AND OF BLACKS PER 1000 BLACK POPULATION; BY STATES, 1870-80 TO 1900-10.

\begin{tabular}{llll}
$1870-80$ & $1880-90$ & $1890-1900$ & $1900-10$ \\
\hline
\end{tabular}

Virginia

White

Black

$-28$

$-50$

$-32$

$-35$

$-83$

$-101$

$-115$

$-89$

North Carolina

White

$-13$

$-29$

$-49$

$-52$

Black

$-85$

$-54$

South Carolina

White

33

$-58$

$-22$

Black

38

$-36$

$-32$

$-107$

Georgia

White

$-39$

$-56$

$-91$

$-31$

Black

$-39$

18

$-40$

$-18$

Florida

White

Black

79

166

$-18$

156

21

131

52

189

Kentucky

White

Black

$-45$

$-83$

160

$-107$

$-65$

$-46$

$-92$

Tennessee

White

Black

$-90$

$-87$

$-98$

$-34$

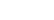

Alabama

White

Black

$-61$

$-75$

$-71$

$-101$

$-54$

$-34$

$-81$

Mississippi

White

Black

$-72$

$-26$

$-61$

$-38$

$-80$

$-11$

13

$-29$

Arkansas

White

Black

132

$-135$

$-83$

$-36$

$-24$

$-39$

Louisiana

White

Black

$-45$

2

42

$-118$

$-74$

215

$-11$

67

Texas

White

347

-36
14

19

26

$14-24 \quad-26$

Black

84

80

59

25

35

32

$-19$

Source: H. EldRmge \& D. Thomas, Population Redistribution and Economic Growth, United States, 1870-1950, in 3 Demographic Analysis and INTERrelations, at Tables A1.19, A1.22 (1964). 
The second observation is that in the decade $1870-80$, the net migration rates were roughly equal for the two races in almost all the states. By the next decade, however, black migration in Tennessee, Alabama, and Mississippi fell relative both to white migration and to previous black migration. The pattern extended to include Georgia, Kentucky, and Arkansas in the 1890's. These migration trends cannot be linked as strongly to state-by-state changes in legislation as the productivity differences can be. Nevertheless, it is clear that some force was operating to reduce black migration in these six quintessentially Southern states.

This is a somewhat different picture than the one drawn by Robert Higgs, who looked at net migration rates for the entire Southern region. ${ }^{81}$ Blacks appear to have migrated as much or more than whites at that level of aggregation. But Higgs's results are dominated by the Atlantic seaboard states. Table 2 shows that his aggregation masks distinctive patterns in the subregions of the South. The southwestern states experienced net immigration of both races, while the Atlantic seaboard states (Virginia and the Carolinas) experienced strong emigration, particularly of blacks. The rest of the South saw substantially less migration of blacks than of whites. Hence, Higgs's conclusion that blacks migrated as much or more than whites holds only for the Atlantic seaboard states and cannot be generalized to the South as a whole.

Outside the Atlantic seaboard, blacks in those states that experienced net outmigration migrated less than did whites. Further, state-by-state black migration rates fell during the Jim Crow era across the South. This fact, too, is concealed by the use of aggregate statistics for the entire Southern region.

\section{Urbanization Evidence}

Evidence of reduced emigration from the Southern states is not by itself sufficient to show the limited mobility of black farm laborers. We must investigate black migration to the Southern cities as well. The hypothesis of limited mobility would suggest that Southern blacks urbanized at a slower rate than Southern whites and that Southern blacks urbanized less quickly than blacks elsewhere.

There are difficulties with evaluating the evidence on this question. First, since 1870 a larger percentage of the black than the white population in every region of the country has lived in cities.

81 R. Higgs, supra note 3, at 27. 
(See Table 3.) Second, if a region shows a decline in the rate of urbanization of blacks relative to whites, we cannot conclude that blacks were staying on the farm. They may have been moving to other regions. With these caveats in mind, we turn to the evidence.

TABLE 3

PERCENT URBAN OF THE NATIVE WHITE AND BLACK POPULATION, 1870 TO 1920

\begin{tabular}{llllll}
1870 & 1880 & 1890 & 1900 & 1910 & 1920 \\
\hline
\end{tabular}

Native White

$\begin{array}{lrrrrrr}\text { Northeast } & 37.9 & 44.6 & 53.3 & 60.8 & 66.5 & 71.5 \\ \text { South } & 7.7 & 8.3 & 12.0 & 14.2 & 19.5 & 25.4 \\ \text { North Central } & 16.8 & 20.9 & 29.5 & 35.5 & 41.7 & 48.9 \\ \text { West } & 21.0 & 25.0 & 35.6 & 39.4 & 47.9 & 51.8 \\ \text { Total U.S. } & 22.4 & 25.8 & 32.7 & 37.8 & 43.5 & 49.5\end{array}$

Black

$\begin{array}{lrrrrrr}\text { Northeast } & 43.7 & 50.5 & 59.8 & 66.1 & 71.1 & 78.7 \\ \text { South } & 8.8 & 9.0 & 13.5 & 15.5 & 19.7 & 23.5 \\ \text { North Central } & 37.1 & 42.6 & 55.8 & 64.4 & 72.6 & 83.4 \\ \text { West } & 45.7 & 51.5 & 54.1 & 67.4 & 78.4 & 76.4 \\ \text { Total U.S. } & 13.4 & 14.3 & 19.7 & 22.6 & 27.3 & 34.0\end{array}$

Source: H. Eldridge \& D. Thomas, Population Redistribution and Economic Growth, United States, 1870-1950, in 3 Demographic ANalysis AND INTERrelations, at Table 1.55 (1964).

There is some evidence in Table 3 that the rate of black urbanization slowed in the South relative to the white rate. By 1910, the percentage of Southern whites who were urban almost equaled the comparable figure for blacks. White urbanization surpassed black urbanization by the end of the decade. This is not true of any other region.

The racial composition of Southern cities changed over the Jim Crow era as well. (See Table 4.) The percentage of Southern urban residents who were black remained constant from the 1870 Census to the 1890 Census. The 1900 and later censuses showed a decline in the fraction of Southern urban residents who were black. 
TABLE 4

PERCENT DISTRIBUTION BY RACE AND NATIVITY OF THE SOUTHERN URBAN POPULATION, 1870 TO 1920

\begin{tabular}{lrrrrrr} 
& 1870 & 1880 & 1890 & 1900 & 1910 & 1920 \\
\cline { 2 - 7 } Native Whites & 50.0 & 53.5 & 56.8 & 60.4 & 65.3 & 69.9 \\
Foreign-born Whites & 15.1 & 11.0 & 7.8 & 5.6 & 4.8 & 4.5 \\
Blacks & 35.0 & 35.5 & 35.3 & 33.8 & 29.8 & 25.4
\end{tabular}

Source: H. Eldradge \& D. Thomas, Population Redistribution and Economic Growth, United States, 1870-1950, in 3 Demographic ANalysis and INTERrRlations, at Table 1.56 (1964).

Thus, Tables 3 and 4 suggest that Southern blacks became urbanized at a slower pace than did Southern whites. Admittedly, blacks could have been leaving Southern cities to go North. But overall state outmigration rates suggest that this could have been true only for the Atlantic seaboard states. My original hypothesis was that restrictive labor legislation reduced the movement of blacks from the Southern agricultural sector. The data on urbanization alone certainly do not (and cannot) prove this hypothesis. Nevertheless, the data suggest that migration to Southern cities was not a significant escape hatch for rural blacks.

A potential weakness in the argument is that Tables 2 and 3 both show that there was substantial mobility on the part of blacks. My point, however, is not that blacks were completely immobilized during this period. My contention, rather, is that Jim Crow labor laws reduced black mobility rates from their previous levels and that blacks became less mobile than whites. Both of these contentions are supported by the evidence.

\section{Conclusion}

The American layman has the impression that the economic oppression of blacks in the Jim Crow South was the result of a universal antipathy of whites towards blacks. He believes that whites were so powerful economically that their private preferences could be translated through the market into segregation and discrimination against blacks. Indeed, the Civil Rights Act of $1964^{82}$ can be said to reflect this view in its prohibition against discrimination by private persons.

Perhaps the time has come to reject this view. There is hardly

2 Civil Rights Act of 1964, Pub. L. No. 88-352, 88 Stat. 251 (1964) (codified as amended in scattered sections of 42 U.S.C. (1982)). 
any question that legal sanctions were necessary to enforce discrimination against blacks. After all, if social pressure, economic power, and custom were sufficient, why did Southern whites bother to enact labor laws in order to extract what was wanted from blacks?

The only real question is the exact role of the law in exploiting blacks. This paper has explored that question in the context of agricultural labor markets. The significance of the specific laws discussed is that they were available to provide a justification for legal action against blacks when such action served the purpose of some white person. The beneficiary might be a specific white employer, as in criminal-surety cases, or the state itself, as in convict leasing. Finally, white planters in general may have benefited from the low wages that arose from the legal system's generally intimidating effects on the black populace. In any case, the evidence indicates that the law, not the market, was the chief oppressor of blacks in the Jim Crow period.

This conclusion has important implications for modern policy. It suggests that it is government, not private individuals, that must be restrained in order to allow disfavored minorities to make substantial economic progress. At first glance, this may seem to be a strange recommendation, but it must be kept in mind that the main focus of the Civil Rights Act of 1964 was on prohibitions of various discriminatory actions by government. The economic progress blacks have made may very well be a result of these prohibitions on government and not of the far more visible prohibitions on discrimination by individuals.

The Jim Crow period also provides an interesting related lesson on the ability of market forces to combat discrimination. Racism was at least as prevalent in the Jim Crow period as it is now. Communities were smaller and more cohesive, making enforcement of social norms easier than today. Yet, social and economic pressure by themselves were not enough to enforce a regime that called for the exploitation of black labor. This suggests that these same market forces could serve minorities well today. And if the market is less competitive than it once was, that problem should be confronted directly. 